\title{
GAYA KEPEMIMPINAN SITUASIONAL TERHADAP MOTIVASI KERJA KARYAWAN PADA PT GARUDA INDONESIA (PERSERO) TBK CABANG KUPANG
}

\author{
Sanjung Koniswara ${ }^{1}$, Tri Suris Lestari ${ }^{2}$ \\ ${ }^{1}$ SEKOLAH TINGGI ILMU EKONOMI OEMATHONIS \\ eks_kupang@yahoo.co.id \\ ${ }^{2}$ SEKOLAH TINGGI ILMU EKONOMI OEMATHONIS \\ trisuris@gmail.com
}

\begin{abstract}
ABSTRAK
Based on Kompas news, it is known that several pilots who are members of the Garuda Pilot Association (APG) conducted a strike because of management problems. Employees (pilots) assume that management always makes unilateral decisions on every policy made. This study aims to determine the effect of situational leadership style on employee work motivation at PT Garuda Indonesia (Persero) Tbk Kupang Branch. The independent variable under study is the situational leadership style $(X)$, while employee work motivation $(Y)$ as the dependent variable is examined. Situational leadership style variables are measured using indicators of instruction, consultation, participation, and delegation. The variable work motivation of employees is measured by using indicators of willingness to assume responsibility, achievement motivation, and engagement. This study uses a sample of 25 respondents, namely the executive employee of PT Garuda Indonesia (Persero) Tbk Kupang Branch. While sampling uses a saturated sampling technique. The data used are primary data and secondary data collected through questionnaires and observations. The results of this study based on the results of the correlation analysis/relationship between situational leadership style and employee work motivation obtained a correlation value of 0.677 which is classified as positive and strong. The results of simple linear regression analysis obtained the equation $Y=31.931+0.599 X, X$ regression coefficient of 0.599 states that every $1 \%$ increase in the value of situational leadership style, the motivation value increases by 0.599. The t-test shows that situational leadership style (variable X) partially proved to have a positive effect on employee work motivation (variable Y). The magnitude of the influence of situational leadership on employee motivation is $45.9 \%$, while $54.1 \%$ is influenced by other factors such as the desire to live, the desire for a position, the desire for power and the desire for recognition, which is not examined by the researcher.

Based on the results of the data analysis, it is suggested that in increasing employee work motivation, it is necessary to have guidance and training in the field of tasks as well as increased motivation related to the needs of employees both internally and externally. For other researchers, it is expected that they can expand the object of their research and not only limited to the PT Garuda Indonesia (Persero) Tbk Kupang Branch but can be done in other institutions related to the objectivity of employee motivation.
\end{abstract}

Keyword : situational leadership, motivation, employees 


\section{PENDAHULUAN}

\section{Latar Belakang Penelitian}

Manajemen merupakan unsur yang sangat penting bagi suatu organisasi agar dapat berjalan dengan baik. Manajemen melibatkan semua fungsi manajemen yang dibutuhkan untuk mencapai tujuan tertentu dari organisasi

Jhon Adair (2008 : 1), sebagai pakar kepemimpinan menyatakan bahwa "kepemimpinan" dan "motivasi" ibarat saudara kandung laki - laki dan perempuan. Sulit dibayangkan seorang pemimpin yang tidak memotivasi orang lain. Setiap pemimpin perlu memiliki gaya kepemimpinan yang dapat membangun motivasi kerja karyawan sehingga menghasilkan tingkat produktivitas tinggi. Pemberian motivasi yang tepat dapat menimbulkan semangat kerja sehingga membuat bawahan dapat menafsirkan tugasnya dan menjalankannya dengan baik.

Selanjutnya Hersery \& Blanchard 1982 (Pasolong, 2008 : 49) menyebutkan empat gaya dasar kepemimpinan situasional yaitu ; (1) Gaya Instruksi Pemimpin, (2) Gaya Konsultasi Pemimpin, (3) Gaya Partisipasi Pemimpin, \& (4) Gaya Delegasi Pemimpin.

Malik (2010) menegaskan bahwa pemimpin dituntut untuk menciptakan dan menerapkan gaya kepemimpinan yang efekif dalam meningkatkan motivasi pada diri karyawan. Karyawan adalah manusia, makhluk yang memiliki perasaan, pikiran, keinginan, status, dan latar belakang yang berbeda - beda. Sehingga dalam mengelola karyawan atau sumber daya manusia, pemimpin harus memperhatikan aspek kemanusiaan, salah satunya melalui motivasi.

Cowley dan Smith (2014) menekankan bahwa setiap karyawan harus memiliki motivasi. Motivasi merupakan dorongan yang membuat karyawan melakukan sesuatu untuk mencapai tujuan tertentu.

Menurut American Encyclopedia motivasi adalah kecendrungan dalam diri seseorang yang membangkitkan topangan dan mengarahkan tindak - tanduknya. Motivasi merupakan faktor kebutuhan biologis dan emosional/fisiologis yang hanya dapat diduga dari pengamatan tingkah laku manusia.
Pemimpin membutuhkan keterampilan untuk memahami dan menciptakan kondisi dimana semua karyawan dapat termotivasi. Ini merupakan tantangan terbesar karena setiap karyawan memiliki perbedaaan karakteristik dan respon pada kondisi yang berbeda. Semua itu merupakan prasyarat untuk mencapai motivasi karyawan yang efektif didukung oleh lingkungan manajemen dan kepemimpinan yang efektif.

Peneliti memilih PT Garuda Indonesia karena PT Garuda Indonesia merupakan salah satu maskapai penerbangan yang ada di Indonesia yang juga merupakan penyedia jasa penerbangan Domestik dan Internasional. Sebagai salah satu maskapai terbaik dunia PT Garuda Indonesia dituntut harus mampu beradaptasi dengan perkembangan zaman dan juga harus tanggap dan responsif terhadap tantangan yang muncul baik itu dari internal perusahaan maupun eksternal perusahaan. Salah satu faktor yang sangat mempengaruhi keberlangsungan hidup atau kinerja perusahaan adalah faktor internal perusahaan yaitu sumber daya manusia (SDM).

Demikian juga yang terjadi di PT Garuda Indonesia ketika terjadi kelemahan pada manajemen sumber daya manusia, baik itu pada kepemimpinannya maupun motivasi kerja karyawan, maka akan mengakibatkan menurunnya kinerja perusahaan. Seperti yang pernah diberitakan pada halaman kompas.com (28/7/2011) yang berjudul "Masalah Garuda seperti Bola Salju".

Tanggerang, Kompas.com- Permasalahan yang ada di PT Garuda Indonesia sudah menjadi masalah yang rumit sejak tahun 2005 . Masalahnya ada di hubungan industrial karena manajemen selalu membuat keputusan sepihak."Tidak ada perjanjian kerjasama, kalaupun ada itu tidak dijalankan" kata Ketua Bidang Humas Serikat Karyawan PT Garuda Indonesia Tomy Tampatty kepada wartawan di ruang Pilot House, Bandara Soaekarno- Hatta, Cengkareng, Kamis (28/7/2011).

Tomy mengibaratkan permasalahan yang ada di tubuh manajemen PT Garuda Indonesia seperti bola salju karena, menurut dia, permasalahan yang ada di perusahaan BUMN tersebut memiliki manajemen yang 
amburadul."Seperti bola es. Selama ini masalahnya adalah manajemen yang paling arogan sejak mereka masuk pada 2005,' ujarnya. Lebih lanjut Tomy menjelaskan, aksi yang dilakukan oleh pihak Asosiasi Pilot Garuda (APG) merupakan bentuk dari kepedulian terhadap perusahaan, di mana para pilot ini bekerja. Ini kepedulian kami untuk Garuda, di sini kami mencari makan, dari sini anak cucu kami hidup, wajar kalau kami peduli terhadap garuda untuk ke depannya" ujarnya. Seperti diberitakan sebelumnya, pihak APG telah menyampaikan aspirasi dalam sejumlah pertemuan dengan pihak manajemen, tetapi tidak pernah menemukan kata sepakat. Bahkan dalam pertemuan terakhir, APG mengaku kecewa dengan pengelolaan manajemen Garuda Indonesia terkait sumber daya manusia (Editor: Hertanto Soebijoto)

Berdasarkan pemberitaan Kompas di atas diketahui bahwa beberapa pilot yang tergabung dalam Asosiasi Pilot Garuda (APG) melakukan mogok kerja karena adanya masalah manajemen. Para karyawan (pilot) memiliki anggapan bahwa manajemen selalu mengambil keputusan sepihak atas setiap kebijakan yang dilakukan. Dijelaskan pula oleh para pilot bahwa mereka melalui APG sudah menyampaikan aspirasi mereka dalam sejumlah pertemuan dengan pihak manajemen, tetapi tidak pernah menemukan kata sepakat.

Kemudian, gaya kepemimpinan situasional dianggap dapat menjadi solusi karena tidak adanya gaya kepemimpinan yang terbaik. Dalam menghadapi permasalahan di atas, PT Garuda Indonesia (Persero) Tbk Cabang Kupang memerlukan gaya kepemimpinan yang bervariasi dari satu situasi ke situasi lainnya tergantung pada kondisi saat dimana dan kapan permasalahan tersebut muncul. Peneliti ingin melihat apakah gaya kepemimpinan situasional berpengaruh terhadap motivasi kerja karyawan.

Berdasarkan masalah yang digambarkan dalam latar belakang masalah tersebut, maka peneliti tertarik untuk melakukan penelitian tentang "Pengaruh Gaya Kepemimpinan Situasional Terhadap Motivasi Kerja Karyawan pada PT Garuda Indonesia (Persero) Tbk Cabang Kupang”.

\section{Perumusan Masalah}

Berdasarkan identifikasi dan batasan masalah yang telah ditetapkan di atas maka rumusan masalah dalam penelitian ini adalah "Apakah gaya kepemimpinan situasional berpengaruh terhadap motivasi kerja karyawan pada PT Garuda Indonesia (Persero) Tbk Cabang Kupang?"

\section{Tujuan Penelitian}

Berdasarkan rumusan masalah tersebut maka ditetapkan tujuan dari penelitian ini yakni: "Untuk mengetahui pengaruh gaya kepemimpinan situasional terhadap motivasi kerja karyawan pada PT Garuda Indonesia (Persero) Tbk Cabang Kupang”

\section{TINJAUAN PUSTAKA \\ Definisi Kepemimpinan}

Definisi kepemimpinan telah dikemukakan oleh berbagai literatur kepemimpinan. Untuk memudahkan memahami pendapat para ahli tersebut, maka akan dikemukakan pendapat sebagai berikut :

Maxwell (Pasolong, 2008:4), kepemimpinan adalah kemampuan memperoleh pengikut. Lebih jauh Maxwell menjelaskan bahwa pemimpin terkemuka suatu kelompok tertentu mudah ditemukan, perhatikan saja orang-orang ketika mereka berkumpul. Kalau suatu persoalan diputuskan, siapa orang yang pandangannya tampak paling berharga, siapa yang diperhatikan, ketika persoalan dibicarakan? Siapa orang yang paling cepat disetujui oleh orang - orang lainnya? Jawaban terhadap semua pertanyaan itu akan membantu menentukan siapa pemimpin yang sesungguhnya dalam suatu kelompok tertentu. Bahkan pengaruh menurut Maxwell merupakan investasi yang paling baik untuk masa depan.

Sedangkan Tzu \& Cleary (2002 : 5), berpendapat lain tentang kepemimpinan adalah sebuah persoalan kecerdasan, kelayakan untuk dipercaya, kelembutan, keberanian, dan ketegasan. Selanjutnya kepemimpinan menurut Nawawi (2004 : 9), adalah kemampuan atau kecerdasan mendorong sejumlah orang (dua orang atau lebih) agar bekerja sama dalam melaksanakan kegiatan - kegiatan yang terarah pada tujuan bersama. 
Kartono (2005 : 153), menyatakan kepemimpinan adalah kemampuan untuk memberikan pengaruh yang konstruktif kepada orang lain untuk melakukan satu usaha kooperatif mencapai tujuan yang sudah direncanakan.

Rivai (2004 : 65), menyatakan kepemimpinan adalah peranan dan juga suatu proses untuk mempengaruhi orang lain.

Dari berbagai definisi di atas, mencerminkan asumsi bahwa kepemimpinan menyangkut sebuah proses pengaruh sosial yang dalam hal ini pengaruh yang sengaja dijalankan oleh seseorang terhadap orang lain untuk menstruktur aktivitas - aktivitas serta hubungan - hubungan di dalam sebuah kelompok. Sehingga dapat disimpulkan bahwa kepemimpinan adalah cara atau gaya yang digunakan pemimpin dalam mempengaruhi pengikut atau bawahannya dalam melakukan kerja sama mencapai tujuan yang telah ditentukan.

\section{Teori Kepemimpinan}

Saat ini masih banyak penelitian dan diskusi yang dilakukan untuk mencari penjelasan atas esensi dari kepemimpinan. Awalnya, teori - teori kepemimpinan berfokus pada kualitas apa yang membedakan antara pemimpin dan pengikut. Adapun teori-teori kepemimpinan, sebagai berikut :

\section{Teori Kontingensi}

Teori kontingensi adalah teori kesesuaian pemimpin, yang berarti berusaha menyesuaikan pemimpin dengan situasi yang tepat. Hal ini disebut kontingensi, karena teori ini menyatakan bahwa keefektifan pemimpin tergantung pada seberapa sesuai gaya pemimpin dengan situasi sekitar. Untuk memahami kinerja pemimpin, penting untuk memahami situasi di mana mereka memimpin. Kepemimpinan yang efektif itu tergantung pada kesesuaian gaya pemimpin dengan latar yang tepat.

Fiedler (Northouse, 2013 : 117) mengembangkan teori kontingensi dengan mempelajari gaya dari banyak pemimpin yang berbeda yang bekerja di konteks yang berbeda, terutama organisasi militer.

Intinya, teori kontingensi terkait dengan gaya dan situasi. Hal itu memberikan kerangka kerja untuk menyesuaikan pemimpin dengan situasi secara efektif.

2. Teori Jalur - Tujuan

Teori Jalur - Tujuan (path - goal) adalah tentang bagaimana pemimpin memotivasi bawahan untuk mencapai tujuan yang telah ditetapkan. Tujuan yang dinyatakan teori kepemimpinan ini adalah untuk meningkatkan kinerja karyawan serta kepuasan karyawan dengan memusatkan pada motivasi karyawan.

Berlawanan dengan pendekatan situasional, yang menyatakan bahwa seseorang pemimpin harus beradaptasi dengan tingkat perkembangan bawahan, dan tidak seperti teori kontingensi, yang menekankan kesesuaian antara gaya pemimpin dan situasi tertentu. Teori jalur tujuan menekankan hubungan antara gaya kepemimpinan dan karakteristik bawahan serta latar pekerjaan. Asumsi itu menyatakan bahwa bawahan akan termotivasi bila mereka berpikir, mereka mampu melaksanakan pekerjaan mereka, bila mereka percaya bahwa upaya mereka akan memberi hasil tertentu, dan bila mereka percaya bahwa hasil yang didapat bernilai.

Bagi pemimpin, tantangannya adalah untuk menggunakan gaya kepemimpinan yang paling memenuhi kebutuhan motivasi karyawan. Menurut Indvik (Northouse, 2013:131), pemimpin mencoba untuk meningkatkan pencapaian tujuan bawahan dengan memberi informasi atau imbalan di dalam lingkungan kerja.

Secara singkat, teori jalur - tujuan didesain untuk menjelaskan bagaimana pemimpin dapat membantu bawahan di sepanjang jalur guna mencapai tujuan mereka, dengan memilih perilaku tertentu yang paling cocok dengan kebutuhan bawahan dan situasi dimana bawahan bekerja.

3. Teori Pertukaran Pemimpin - Anggota

Teori pertukaran pemimpin - anggota (leader - member exchange/LMX) menelusuri dengan diam - diam pendekatan lain serta mendefinisikan kepemimpinan sebagai proses yang terpusat pada interaksi antara pemimpin dan pengikut. Teori ini 
membuat hubungan dua pihak antara pemimpin dan pengikut, titik utama dari proses kepemimpinan.

Teori LMX ini menantang asumsi yang menyatakan bahwa pemimpin memperlakukan pengikut dalam cara kolektif, sebagai kelompok, dengan menggunakan gaya kepemimpinan rata rata, dan mengarahkan ke perbedaan yang bisa muncul antara pemimpin dan masing masing dari pengikut pemimpin.

\section{Gaya Kepemimpinan}

Gaya pada dasarnya berasal dari bahasa Inggris "Style" yang berarti mode seseorang yang selalu nampak dan menjadi ciri khas orang tersebut. Gaya merupakan kebiasaan yang melekat pada diri seseorang dalam tugas - tugas kepemimpinannya.

Gaya kepemimpinan menurut Thoha (2004:49), adalah norma perilaku yang digunakan oleh seseorang pada saat orang tersebut mencoba mempengaruhi orang lain.

Hasibuan (2017 : 170) menyatakan bahwa cara/gaya/tipe kepemimpinan memiliki makna yang bertujuan untuk mendorong gairah kerja, kepuasaan kerja, dan produktivitas kerja karyawan yang tinggi, agar dapat mencapai tujuan organisasi yang maksimal. Adapun beberapa gaya kepemimpinan, yakni sebagai berikut :

\section{Gaya Kepemimpinan Otoriter}

Gaya kepemimpinan otoriter adalah kekuasaan atau wewenang sebagaian besar mutlak tetap berada pada pimpinan. Pengambilan keputusan dan kebijaksanaan hanya ditetapkan sendiri oleh pemimpin, bawahan tidak diikutsertakan untuk memberikan saran, ide, dan pertimbangan dalam proses pengambilan keputusan.

2. Gaya Kepemimpinan Partisipasif

Gaya kepemimpinan partisipasif yaitu dalam proses kepemimpinannya dilakukan dengan cara persuasif, menciptakan kerjasama yang serasi, menumbuhkan loyalitas, dan partisipasi para bawahan. Pemimpin memotivasi bawahan agar merasa ikut memiliki perusahaan.

3. Gaya Kepemimpinan Delegatif

Gaya kepemimpinan delegatif apabila seorang pemimpin mendelegasikan wewenang kepada bawahan dengan agak lengkap.

4. Gaya Kepemimpinan Situasional

Menurut gaya kepemimpinan situasional, tidak ada satu pun cara yang terbaik untuk mempengaruhi orang lain. Gaya kepemimpinan mana yang harus digunakan terhadap individu atau kelompok tergantung pada tingkat kesiapan orang yang akan dipengaruhi.

\section{Gaya Kepemimpinan Situasional}

Model kepemimpinan situasional dikembangkan oleh Paul Hersey dan Kenneth H. Blanchard di Pusat Studi Kepemimpinan pada akhir tahun 1960. Fokus pendekatan situasional terhadap kepemimpinan terletak pada perilaku yang diobservasi atau perilaku nyata yang terlihat, bukan pada kemampuan atau potensi kepemimpinan yang dibawa sejak lahir. Penekanan pendekatan situasional adalah perilaku pemimpin dan anggota/pengikut dalam kelompok dan situasi yang variatif (Hasibuan, $2017:$ 173).

Menurut Tjiptono (2004 : 162) menyatakan bahwa kepemimpinan situasional dikenal pula sebagai kepemimpinan tidak tetap (fluid) atau kontingensi. Asumsi yang digunakan dalam teori ini adalah bahwa tidak ada satu pun gaya kepemimpinan yang tepat bagi setiap pemimpin dalam segala kondisi. Karena itu gaya kepemimpinan situasional akan menerapkan suatu gaya tertentu berdasarkan pertimbangan atas faktor - faktor seperti pemimpin, pengikut, dan situasi dalam arti struktur tugas, peta kekuasaan, dan dinamika kelompok.

Kepemimpinan situasional menurut Hersey \& Blanchard (Pasolong, 2008 : 48) di dasarkan pada saling berhubungan dengan : (1) jumlah petunjuk dan pengarahan yang diberikan oleh pimpinan, (2) jumlah dukungan sosioemosional yang diberikan oleh pimpinan, (3) tingkat kematangan atau kesiapan para pengikut yang ditunjukkan dalam melaksanakan tugas khusus, fungsi atau tujuan tertentu.

Gaya kepemimpinan yang sesuai (gaya pemimpin) bagi level kematangan tertentu dari pengikut digambarkan dengan kurve perspektif yang bergerak melalui keempat kuadran 
kepemimpinan. Kurva berbentuk lonceng itu disebut "kurva perspektif" karena hal itu menunjukan gaya kepemimpinan yang sesuai langsung di atas level kematangan yang berkatian. Adapun gaya kepemimpinan situasional dari Hersey \& Blanchard, yaitu sebagai berikut : 1) Instruksi : yaitu diterapkan kepada bawahan yang memiliki tingkat kematangan yang rendah. Dalam hal ini bawahan tidak mampu dan tidak mau (M1) memikul tanggung jawab untuk melaksanakan tugas. Dalam banyak kasus ketidakinginan bawahan merupakan akibat dari ketidakyakinan atau kurangnya pengalaman dan pengetahuannya berkenaan dengan sesuatu tugas. Dengan demikian gaya pengarahan (G1) yang jelas dan spesifik yang cocok diterapkan oleh pemimpin. Oleh karena itu, perilaku instruksi pemimpin dirujuk, karena dicirikan dengan peranan pemimpin yang menginstruksikan bawahan tentang apa, bagaimana, dan dimana harus melakukan sesuatu tugas tertentu. 2) Konsultasi : yaitu diterapkan kepada bawahan yang mempunyai tingkat kematangan rendah ke sedang. Dalam hal ini bawahan yang tidak mampu tetapi berkeinginan (M2) untuk memikul tanggung jawab, yaitu memiliki keyakinan tetapi kurang memiliki pengetahuan dan ketrampilan. Dengan demikian gaya konsultasi (G2) yang memberikan perilaku mengarahkan karena mereka kurang mampu, juga memberikan dukungan untuk memperkuat kemampuan dan antusias. Perilaku konsultasi yang dirujuk karena hampir seluruh pengarahan masih dilakukan oleh pemimpin. Namun melalui komunikasi dua arah dan penjelasan pemimpin melibatkan bawahan dengan mencari saran dan jawaban atas permasalahan - permasalahan. Komunikasi dua arah ini membantu dalam mempertahankan tingkat motivasi bawahan yang tinggi pada saat yang sama tanggung jawab dan kontrol atas pembuatan keputusan tetap ada pada pimpinan. 3) Partisipasi : yaitu diterapkan kepada bawahan yang memiliki tingkat kematangan dari sedang ke tinggi. Bawahan pada tingkat perkembangan ini, memiliki kemampuan tetapi tidak memiliki kemauan (M3) untuk melakukan suatu tugas yang diberikan. Ketidakinginan bawahan sering kali disebabkan karena kurangnya keyakinan. Namun bila mereka yakin atas kemampuannya tetapi tidak mau, maka keengganan mereka untuk melaksanakan tugas tersebut lebih merupakan persoalan motivasi dibandingkan persoalan keamanan. Dengan demikian perilaku yang mendukung, tanpa mengarahkan yaitu partisipasi (G3) mempunyai tingkat keberhasilan yang tinggi untuk diterapkan bagi bawahan dengan tingkat kematangan seperti ini. Gaya ini disebut partisipasi karena pemimpin dan pengikut saling bertukar menukar ide dalam melaksanakan tugas, dengan peranan pemimpin yang utama memberikan fasilitas dan berkomunikasi. 4) Delegasi : yaitu diterapkan kepada bawahan yang memiliki tingkat kematangan tinggi yaitu mampu dan mau (M4). Dengan demikian gaya "delegasi" yang berprofil rendah (G4) yang memberikan sedikit pengarahan atau dukungan memiliki tingkat kemungkinan efektif yang paling tinggi. Bawahan diperkenankan untuk melaksanakan sendiri dan memutuskannya tentang bagaimana, kapan, dan dimana melakukan pekerjaan. Gaya ini melibatkan perilaku hubungan kerja yang rendah dan perilaku pada tugas juga rendah.

Faktor kunci penerapan kepemimpinan situasional adalah penilaian tingkat kematangan pengikut dan selanjutnya menerapkan perilaku seperti yang diuraikan. Telah dikemukakan bahwa faktor kunci bagi kepemimpinan yang efektif adalah mengidentifikasi level kematangan individu atau kelompok yang hendak dipengaruhi untuk selanjutnya menggunakan gaya kepemimpinan yang sesuai.

Kematangan (maturity) dirumuskan oleh Thoha (2007 : 322), sebagai kemampuan dan kemauan orang - orang untuk bertanggung jawab dalam mengarahkan perilakunya sendiri. Sedangkan menurut Rivai (Paslong, 2008 : 52), menyatakan bahwa kematangan dipandang sebagai kapasitas untuk menetapkan tujuantujuan yang betapapun juga tingginya dapat dicapai (motivasi keberhasilan), kesediaan dan kemampuan untuk mengambil tanggung jawab, pendidikan dan atau pengalaman seseorang atau suatu kelompok. Hal senada dirumuskan oleh Silalahi (Pasolong, 2008:52) bahwa kematangan adalah sebagai kemampuan (ability) dan kemauan (willingnes) orang-orang 
untuk memikul tanggung jawab untuk mengerahkan perilaku mereka sendiri

\section{Definisi Motivasi}

Istilah motivasi diambil dari istilah Latin movere, yang berarti "pindah". Dalam konteks sekarang motivasi adalah "proses - proses psikologis meminta mengarahkan, arahan, dan menetapkan tindakan sukarela yang mengarah pada tujuan". Para manejer perlu memahami proses psikologis ini jika mereka ingin berhasil memandu para karyawan menuju mencapai sasaran organisasi. Dengan kata lain Kreitner dan Kinicki (2000 : 248) mendefinisikan motivasi sebagai proses pisikologis yang meningkatkan dan mengarahkan perilaku untuk mencapai tujuan.

Motivasi merupakan hasil interaksi antara individu dengan situasi. Tentu saja, setiap individu memiliki dorongan motivasional dasar yang berbeda - beda. Ketika mengenali konsep motivasi, terdapat tingkatan motivasi yang berbeda - beda antara setiap individu serta antara individu dengan situasi. Motivasi adalah proses yang menjelaskan intensitas, arah, dan ketekunan usaha untuk mencapai suatu tujuan (Robins dan Judge, 2008 : 222).

Tiga elemen utama dalam definisi di atas adalah intensitas, arah, dan ketekunan. "Intensitas" berhubungan dengan seberapa giat seseorang berusaha. Ini adalah elemen yang paling banyak mendapat perhatian ketika kita membicarakan tentang motivasi. Namun, intensitas yang tinggi sepertinya tidak akan menghasilkan prestasi kerja yang memuaskan kecuali upaya tersebut dikaitkan dengan "arah" yang menguntungkan organisasi. Dengan demikian, kita harus mempertimbangkan kualitas serta intensitas upaya yang seharusnya kita lakukan. Terakhir, motivasi memiliki dimensi "ketekunan". Dimensi ini merupakan ukuran mengenai berapa lama seseorang bisa mempertahankan usahanya. Individu - individu yang termotivasi bertahan melakukan suatu tugas dalam waktu yang cukup lama demi mencapai tujuan mereka (Robins dan Judge, 2008 : 223).

Menurut Wexly \& Yulk (Pasolong, 2008 : 140), mengatakan bahwa motivasi kerja adalah pemberian dorongan atau sesuatu yang melatarbelakangi seseorang untuk melakukan sesuatu atau tingkah laku. Menurut Hasibuan (Syaiyid, Utami, dan Riza, 2013: 106), motivasi kerja mempersoalkan bagaimana cara mendorong gairah kerja bawahan, agar mereka mau bekerja keras dengan memberikan semua kemampuan dan keterampilannya untuk mewujudkan tujuan perusahaan.

Dengan demikian, kunci utama untuk memahami proses motivasi kerja bergantung pada pengertian dan hubungan antara kebutuhan dan dorongan.

\section{Teori Motivasi}

\section{Teori Hirarki Kebutuhan}

Sering dikatakan orang bahwa teori motivasi yang paling terkenal adalah hierarki kebutuhan (hierarchy of needs) milik Abraham Maslow. Ia membuat hipotesis bahwa dalam setiap diri manusia terdapat hierarki dari lima kebutuhan. Kebutuhan - kebutuhan dasar tersebut adalah: (1) Fisiologis; meliputi rasa lapar, haus, berlindung, seksual, dan kebutuhan fisik lainnya. (2) Rasa aman; meliputi rasa ingin dilindungi dari bahaya fisik dan emosional. (3) Sosial; meliputi rasa kasih sayang, kepemilikan, penerimaan, dan persahabatan. (4) Penghargaan; meliputi faktor - faktor penghargaan internal seperti hormat diri, otonomi, dan pencapaian, dan faktor - faktor penghargaan eksternal seperti status, pengakuan, dan perhatian. (5) Aktualisasi diri; dorongan untuk menjadi seseorang sesuai kecakapannya; meliputi pertumbuhan, pencapaian potensi seseorang, dan pemenuhan diri sendiri (Robins dan Judge, 2008 : 223).

Ketika setiap kebutuhan pada dasarnya terpenuhi, kebutuhan yang berikutnya menjadi dominan. Dari sudut motivasi meskipun tidak ada kebutuhan yang benar benar dipenuhi, sebuah kebutuhan yang pada dasarnya telah dipenuhi tidak lagi memotivasi. Jadi bila ingin memotivasi seseorang, menurut Maslow, anda harus memahami tingkat hierarki di mana orang tersebut berada saat ini dan fokus untuk memenuhi kebutuhan - kebutuhan di atas tingkat tersebut. 


\section{Teori Dua Faktor}

Teori dua faktor (two factor theory), juga disebut teori motivasi higiene (motivation hygiene theory), dikemukakan oleh seorang psikolog bernama Frederick Herzberg. Dengan keyakinan bahwa hubungan seorang individu dengan pekerjaan adalah mendasar dan bahwa sikap seorang terhadap pekerjaan bisa sangat baik menentukan keberhasilan atau kegagalan. Herzberg menyelidiki pertanyaan tersebut "Apa yang diinginkan individu dari pekerjaan - pekerjaan mereka?”. Ia meminta individu untuk mendeskripsikan, secara mendetail, situasi - situasi di mana mereka merasa luar biasa baik atau buruk dengan pekerjaan - pekerjaan mereka. Respon respon tersebut kemudian ditabulasi dan dikategorisasikan (Robins dan Judge, 2008 : 227).

Dari respon - respon yang dikategorisasikan, Herzberg menyimpulkan bahwa jawaban - jawaban yang diberi oleh individu ketika mereka merasa baik dengan pekerjaan - pekerjaan mereka berbeda secara signifikan dari jawaban - jawaban yang diberikan ketika mereka merasa buruk. Faktor - faktor intrinsik, seperti kemajuan, pengakuan, tanggung jawab dan pencapaian tampaknya berhubungan dengan kepuasan menghubungkan faktor - faktor ini dengan diri mereka sendiri. Namun responden responden yang tidak puas cenderung menyebutkan faktor - faktor ekstrinsik, seperti pengawasan, imbalan kerja kebijaksanaan perusahaan, dan kondisi kondisi kerja.

Menurut Herzberg bahwa lawan dari kepuasan bukanlah ketidakpuasan, seperti pada umumnya kita ketahui. Menghilangkan karakteristik-karakteristik yang tidak memuaskan dari suatu pekerjaan belum tentu membuat pekerjaan tersebut memuaskan. Herzberg mengemukakan bahwa penemuannya menunjukan adanya kesatuan rangkap; lawan dari "kepuasan" adalah bukan kepuasan, dan lawan dari "ketidakpuasan" adalah "bukan ketidakpuasan".
3. Teori X dan Y Dari Douglas McGregor

Douglas McGregor mengemukakan dua pandangan nyata mengenai manusia : pandangan pertama pada dasarnya negatif, disebut "Teori X" (Theory X), dan yang kedua pada dasarnya positif, disebut "Teori Y" (Theory Y). Setelah mengkaji cara para manajer berhubungan dengan para karyawan, McGregor menyimpulkan bahwa pandangan manajer mengenai sifat manusia didasarkan atas beberapa kelompok asumsi tertentu dan bahwa mereka cenderung membentuk perilaku mereka terhadap karyawan berdasarkan asumsi - asumsi tersebut (Robins dan Judge, 2008 : 225).

Menurut teori X, empat asumsi yang dimiliki oleh manajer (Robins dan Judge, 2008 : 226) adalah: (1) Karyawan pada dasarnya tidak menyukai pekerjaan dan sebisa mungkin berusaha untuk menghindarinya. (2) Karena karyawan tidak menyukai pekerjaan, mereka harus dipaksa, dikendalikan, atau diancam dengan hukuman untuk mencapai tujuan - tujuan. (3) Karyawan akan menghindari tanggung jawab dan mencari perintah formal bila mungkin. (4) Sebagai karyawan menempatkan keamanan diatas semua faktor lain terkait pekerjaan dan menunjukan sedikit ambisi.

Bertentangan dengan pandangan pandangan negatif mengenai sifat - sifat manusia dalam teori $\mathrm{X}, \mathrm{McGregor}$ menyebutkan empat asumsi positif yang disebutkan sebagai teori Y (Robins dan Judge, 2008 : 226): (1) Karyawan menganggap kerja sebagai hal yang menyenangkan, seperti halnya istirahat atau bermain. (2) Karyawan akan berlatih mengendalikan diri dan emosi untuk mencapai berbagai tujuan. (3) Karyawan bersedia belajar untuk menerima, bahkan mencari, tanggung jawab. (4) Karyawan mampu membuat berbagai keputusan inovatif yang diedarkan ke seluruh populasi, dan bahkan hanya bagi mereka yang menduduki posisi manajemen.

\section{Prinsip Motivasi}

Prinsip - prinsip motivasi menurut Adair (2008:103), adalah sebagai berikut : 1) 
Pemimpin sendiri harus termotivasi, 2) Pilih orang yang bermotivasi tinggi, 3) Perlakukan setiap orang sebagai individu, 4) Tetapkan sasaran yang realistis, 5) Kemajuan akan motivasi, 6) Ciptakan lingkungan yang memotivasi, 7) Memberikan penghargaan, 8) Memberikan pengakuan

\section{Metode Motivasi}

Menurut Hasibuan (2017 : 149) ada dua metode motivasi yaitu motivasi langsung dan motivasi tak langsung, yakni :

1. Motivasi Langsung (Direct Motivation): Motivasi langsung adalah motivasi (materiil \& nonmateriil) yang diberikan secara langsung kepada setiap individu karyawan untuk memenuhi kebutuhan serta kepuasaannya. Jadi sifatnya khusus, seperti pujian, penghargaan, tunjangan hari raya, bonus, dan bintang jasa.

2. Motivasi Tak Langsung (Indirect Motivation): Motivasi tak langsung adalah motivasi yang diberikan hanya merupakan fasilitas - fasilitas yang mendukung serta menunjang gairah kerja/kelancaran tugas sehingga para karyawan betah dan bersemangat melakukan pekerjaannya. Misalnya, kursi yang empuk, mesin - mesin yang baik, ruangan kerja yang terang dan nyaman, suasana pekerjaan yang serasi, serta penempatan yang tepat. Motivasi tidak langsung besar pengaruhnya untuk merangsang semangat bekerja karyawan sehingga produktif.

\section{Hubungan Gaya Kepemimpinan Situasional dengan Motivasi Kerja Karyawan}

Kebanyakan pimpinan harus memotivasi suatu kelompok orang yang berbeda - beda dalam banyak hal tidak dapat diperkirakan. Keragaman timbul dari pola - pola perilaku yang berbeda yang dalam keadaan tertentu berkatian dengan kebutuhan dan tujuan. "Kebutuhan" adalah kekurangan yang dialami individu pada suatu waktu tertentu. Kekurangan tersebut dapat bersifat fisik, psikologis, atau sosiologis.

Douglas McGregor mengemukakan dua pandangan nyata mengenai manusia : pandangan pertama pada dasarnya negatif, disebut "Teori X" (Theory $X$ ), dan yang kedua pada dasarnya positif, disebut "Teori Y"
(Theory $Y$ ). Karyawan dengan asumsi teori $\mathrm{x}$ adalah karyawan dengan tipe yang pemalas dan cenderung tidak mau menerima tanggung jawab sedangkan, asumsi teori y adalah karyawan dengan tipe yang rajin dan bertanggung jawab dalam memikul sebuah tanggung jawab (Robins dan Judge, 2008 : 225).

Dari penjelasan konsep di atas bahwa motivasi merupakan imbas atau dampak dari hasil interaksi antara pimpinan dan bawahan. Interaksi yang salah antara pimpinan dan bawahan akan mengakibatkan tidak adanya motivasi pada bawahan sedangkan interaksi yang tepat dari pimpinan pada bawahan akan memberikan motivasi yang tinggi.

\section{Penelitian Terdahulu}

Untuk mendukung penelitian tentang "Pengaruh Gaya Kepemimpinan Situasional Terhadap Motivasi Kerja Karyawan Pada PT Garuda Indonesia (Persero) Tbk Cabang Kupang", perlu dikemukakan penelitian sejenis diantaranya:

1. Penelitian yang dilakukan oleh Fifil Khoironi (2011), yang berjudul "Pengaruh Gaya Kepemimpinan Situasional Terhadap Motivasi Kerja Karyawan pada Taman Rekreasi Sengkaling". Penelitian ini bertujuan untuk mengetahui gaya kepemimpinan dan untuk mengetahui apakah gaya kepemimpinan situasional berpengaruh signifikan pada motivasi kerja karyawan pada Taman Rekreasi Sengkaling Malang. Teknik analisis data menggunakan Rentang Skala dan Regresi Linear Berganda. Hasil penelitian diketahui bahwa gaya kepemimpinan yang terjadi pada taman rekreasi Sengkaling mengarah pada gaya kepemimpinan konsultasi, berdasarkan hasil perhitungan rentang skala menunjukkan bahwa Perilaku Tugas dan Perilaku hubungan Taman Rekreasi Sengkaling sangat tinggi. Motivasi kerja karyawan pada Taman Rekreasi Sengkaling sangat tinggi. Berdasarkan hasil uji statistik maupun kondisi empirik pada perusahaan diketahui bahwa Perilaku Tugas, Perilaku Hubungan, Kematangan Pekerjaan dan Kematangan Psikologis merupakan faktor yang menentukan motivasi kerja karyawan dan mempunyai pengaruh dengan koefisien 
determinasi 0,869 artinya kontribusi pengaruhnya sebesar $86 \%$. Selanjutnya setelah dilakukan uji t, variabel perilaku tugas, hubungan, kematangan karyawan dan psikologis mempunyai pengaruh yang signifikan terhadap motivasi kerja karyawan.

2. Penelitian yang dilakukan oleh Sinollah (2014), yang berjudul "Pengaruh Gaya Kepemimpinan Situasional Terhadap Motivasi Kerja Karyawan CV. Duta Bangsa Pasuruan". Penelitian tujuan yang ingin dicapai adalah untuk mengetahui pengaruh gaya kepemimpinan situasional pada CV. Duta Bangsa Pasuruan. Hasil penelitian ini menunjukkan bahwa variabel gaya kepemimpinan situasional tidak seberapa berpengaruh terhadap motivasi kerja karyawan dengan pengaruh hanya $6,3 \%$. Dan hasil analisis juga menunjukkan bahwa variabel gaya kepemimpinan situasional kurang berpengaruh secara dominan terhadap motivasi kerja karyawan dengan koefisien regresi 0,462 .

3. Penelitian yang dilakukan oleh Aditya Gunawan Syamsudin, Djabir Hamzah, Shinta Dewi Tikson (2016), yang berjudul "Pengaruh Gaya Kepemimpinan Situasional Terhadap Motivasi Kerja Karyawan pada PT Semen Tonasa (Persero) Tbk". Penelitian ini bertujuan untuk mengetahui pengaruh gaya kepemimpinan situasional terhadap motivasi kerja karyawan pada PT Semen Tonasa (Persero) Tbk. Variabel independen yang diteliti yaitu Instruksi (X1), Konsultasi (X2), Partisipasi (X3), dan Delegasi (X4). Sedangkan motivasi kerja karyawan (Y) sebagai variabel dependen yang diteliti. Hasil penelitian ini menunjukkan bahwa berdasarkan hasil analisis regresi linear berganda diperoleh persamaan $\mathrm{Y}=9,529+$ $0,696 \mathrm{X} 1+0,732 \mathrm{X} 2-0,108 \mathrm{X} 3+0,520 \mathrm{X} 4$. Variabel yang memiliki pengaruh paling signifikan dan dominan terhadap motivasi kerja karyawan adalah gaya kepemimpinan model instruksi (X1) dengan koefisien sebesar 0,696. Nilai koefisien determinasi $\mathrm{R}$ Square sebesar 0,478, artinya keempat variabel turunan gaya kepemimpinan situasional yakni X1, X2, X3 dan X4 memiliki pengaruh sebesar $47,8 \%$ terhadap motivasi kerja karyawan, sedangkan sisanya sebesar 52,2\% dipengaruhi oleh faktor faktor lain yang tidak termasuk dalam penelitian ini.

\section{Kerangka Pemikiran}

Kerangka pemikiran mencoba untuk menggambarkan hubungan antara gaya kepemimpinan situasional (variabel $\mathrm{x}$ ) dengan motivasi kerja karyawan (variabel y). Gaya kepemimpinan situasional diukur dari beberapa indikator yaitu ; instruksi, konsultasi, partisipasi, dan delegasi. Keempat indikator dari gaya kepemimpinan situasional ini akan mempengaruhi motivasi karyawan.

Gambar 2.2. Kerangka Pemikiran

\begin{tabular}{|l|l|l|}
\hline \multicolumn{1}{|c|}{ Gaya } \\
Kepemimpinan \\
Situasional (x) : \\
$\begin{array}{l}\text { 1. Instruksi } \\
\text { 2. Konsultasi } \\
\text { 3. Partisipasi } \\
\text { 4. Delegasi }\end{array}$ & $\begin{array}{l}\text { Motivasi (y) : } \\
\text { 1. Kemauan } \\
\text { untuk memikul } \\
\text { tanggungjawab } \\
\text { 2. Motivasi } \\
\text { berprestasi }\end{array}$ \\
\hline 3ipotesis & 3eikatan \\
\hline
\end{tabular}

Dalam kerangka berpikir telah digambarkan dan dijelaskan bahwa setiap perlakuan pemimpin atau gaya kepemimpinan diterapkan berbeda pada situasi yang berbeda pula. Oleh karena itu dalam penelitian ini ditarik hipotesis sebagai berikut:

1. Terdapat pengaruh yang signifikan antara gaya kepemimpinan situasional terhadap motivasi kerja karyawan pada PT Garuda Indonesia (Persero) Tbk Cabang Kupang.

2. Tidak terdapat pengaruh yang signifikan antara gaya kepemimpinan situasional terhadap motivasi kerja karyawan pada PT Garuda Indonesia (Persero) Tbk Cabang Kupang.

\section{METODE PENELITIAN \\ Populasi dan Sampel}

Populasi menurut Sugiyono (2004 : 90) adalah wilayah generalisasi yang terdiri atas obyek/subyek yang mempunyai kualitas dan karakteristik tertentu yang ditetapkan oleh peneliti untuk dipelajari dan kemudian ditarik kesimpulannya. Berdasarkan penjelasan tersebut maka dalam penelitian ini yang menjadi populasi adalah seluruh karyawan 
pelaksana PT Garuda Indonesia (Persero) Tbk Cabang Kupang yang berjumlah 25 orang

Selanjutnya, sampel menurut Sugiyono (2004 : 91) adalah bagian dari jumlah dan karakteristik yang dimiliki oleh populasi tersebut. Dalam penelitian ini penentuan sampelnya menggunakan teknik sampling jenuh. Sampling jenuh adalah teknik penentuan sampel apabila semua anggota populasi digunakan sebagai sampel (Sugiyono, 2013 : 96). Hal ini sering dilakukan bila jumlah populasi relatif kecil, kurang dari 30 orang.

\section{Definisi Operasional Variabel Penelitian}

Definisi operasional dalam penelitian ini adalah sebagai berikut :

1. Gaya Kepemimpinan Situasional

Gaya kepemimpinan situasional adalah perilaku pemimpin PT Garuda Indonesia (Persero) Tbk Cabang Kupang, berbentuk instruksi, konsultasi, partisipasi, dan delegasi yang diukur dengan dua instrumen pokok yaitu perilaku tugas dan hubungan.

Indikator yang digunakan dalam penelitian ini adalah :

a. Instruksi adalah perintah atau arahan dari atasan (untuk melakukan suatu pekerjaan atau melaksanakan suatu tugas) kepada karyawan.

b. Konsultasi adalah pertukaran pikiran untuk mendapatkan kesimpulan (nasihat, saran, dan sebagainya) yang sebaik baiknya dari atasan kepada karyawan.

c. Partisipasi merupakan perihal turut berperan serta dalam suatu kegiatan, keikutsertaan atau peran serta.

d. Delegasi adalah perwakilan atau utusan dengan proses penunjukan secara langsung maupun secara musyawarah untuk mengutusnya menjadi salah satu perwakilan.

2. Motivasi

Motivasi adalah dorongan yang timbul dalam diri karyawan karena adanya suatu kebutuhan untuk mencapai suatu tujuan tertentu.

Indikator yang digunakan dalam penelitian ini adalah :

a. Kemauan memikul tanggung jawab adalah kerelaan atau kewajiban dalam menanggung suatu pekerjaan yang harus diselesaikan tepat pada waktunya dan sesuai dengan target yang telah ditentukan.

b. Motivasi berprestasi merupakan faktor pendorong untuk menentukan keberhasilan dalam bekerja dan untuk atau mencapai sesuatu yang diinginkan oleh pimpinan dan perusahaan.

c. Keikatan merupakan suatu kondisi yang dirasakan oleh karyawan yang dapat menimbulkan perilaku positif yang kuat terhadap pekerjaan dan perusahaan.

\section{Uji Validitas \& Reliabilitasnya}

\section{Validitas}

Uji validitas dilakukan berkenaan dengan ketepatan alat ukur terhadap konsep yang diukur sehingga benar - benar mengukur apa yang seharusnya diukur. Berkaitan dengan pengujian validitas intrumen menurut Riduwan (2007: 109- 110) menjelaskan bahwa validitas adalah suatu ukuran yang menunjukkan tingkat keandalan atau kesahihan suatu alat ukur. Untuk menghitung validitas, alat ukur digunakan rumus Pearson Product Moment adalah :

$r=\frac{n \sum X Y-\sum X \sum Y}{\left.\sqrt{\left\{n \sum X^{2}\right.}-\left(\sum X\right)^{2}\right\}\left\{n \sum Y^{2}-\left(\sum Y\right)^{2}\right\}}$

Dimana:

$\mathrm{r}=$ Korelasi

$\mathrm{X}=$ Jumlah skor item

$\mathrm{Y}=$ Jumlah skor total (seluruh item)

$\mathrm{n}=$ jumlah responden

Distribusi (Tabel t) untuk $\alpha=0,05$ dan derajat kebebasan $(\mathrm{dk}=\mathrm{n}-2)$. Kaidah keputusan :

Jika $r$ hitung $>r$ tabel berarti valid sebaliknya

$r$ hitung $<r$ tabel berarti tidak valid

\section{Reliabilitas}

Reliabilitas adalah petunjuk sejauh mana sebuah instrument dapat memberikan hasil yang tidak berbeda jika dilakukan pengukuran ulang. Pemahaman diperkuat oleh Sugiyono (2007 : 110) mengatakan bahwa instrumen yang reliabel adalah instrumen yang bila digunakan beberapa kali untuk mengukur objek yang sama, akan menghasilkan data yang sama, jika croanbach alpha lebih dari nilai 0,6 sesuai yang diisyaratkan. Perhitungan ini menggunakan rumus Alpha (Riduwan, 2004). Untuk 
keperluan analisa reliabilitas menggunakan bantuan komputer program SPSS versi 22.00.

\section{Teknik Analisis Data}

Untuk keperluan analisis data, harus ditingkatkan menjadi skala interval dengan menggunakan method of successive interval yang diperoleh dengan bantuan SPSS versi 22.00 sesudah data tersebut ditingkatkan menjadi skala interval, maka langkah selanjutnya adalah:

1. Menganalisis hubungan antara gaya kepemimpinan situasional terhadap motivasi kerja karyawan pada PT Garuda Indonesia (Persero) Tbk Cabang Kupang dengan menggunakan rumus koefisien korelasi (Sugiyono, 2004) sebagai berikut:

$$
r=\frac{n \sum X_{i} Y_{i}-\left(\sum X_{i}\right) \sum Y_{i}}{\left.\sqrt{\left\{n \sum X_{i}^{2}\right.}-\left(\sum X_{i}\right)^{2}\right\}\left\{n \sum Y_{i}{ }^{2}-\left(\sum Y_{i}\right)^{2}\right\}}
$$

Keterangan:

$\mathrm{r}=$ Koefisien korelasi

$\mathrm{n}=$ Jumlah data observasi

$\mathrm{x}=$ Variabel bebas (gaya kepemimpinan situasional)

$\mathrm{y}=$ Variabel terikat (motivasi)

Jika nilai $\mathrm{r}=1$ : maka kedua variabel mempunyai hubungan yang positif, dan jika $\mathrm{r}=-1$ : maka kedua variabel mempunyai hubungan yang negatif, sedangkan jika $r=0$ : maka tidak ada hubungan antara dua variabel.

2. Menganalisis pengaruh antara gaya kepemimpinan situasional terhadap motivasi kerja karyawan pada PT Garuda Indonesia (Persero) Tbk Cabang Kupang dengan menggunakan regresi linear sederhana Setelah melakukan perhitungan dan telah diketahui nilai untuk a dan $b$, kemudian nilai tersebut dimasukkan ke dalam persamaan regresi linear sederhana untuk mengetahui perubahan yang terjadi pada variabel motivasi kerja karyawan berdasarkan nilai variabel gaya kepemimpinan situasional yang diketahui. Persamaan regresi yang telah ditemukan dapat digunakan untuk melakukan prediksi bagaimana individu dalam variabel terikat akan terjadi bila individu variabel bebas ditetapkan.

Setelah persamaan regresi telah ditentukan, selanjutnya melakukan pengujian hipotesis. Dalam penelitian ini, pengujian hipotesis dilakukan dengan menggunakan uji t (parsial). Tujuan dari uji parsial adalah untuk mengetahui pengaruh dari variabel gaya kepemimpinan situasional terhadap variabel motivasi kerja karyawan secara parsial.

3. Menghitung besarnya pengaruh gaya kepemimpinan situasional terhadap motivasi kerja karyawan pada PT Garuda Indonesia (Persero) Tbk Cabang Kupang dengan koefisien determinal (KD) atau koefisien penentu (KP)

\section{Hasil Uji Validitas dan Reliabilitas}

\section{Hasil Uji Validitas}

Setelah uji instrumen dilakukan, hal selanjutnya yang dilakukan peneliti adalah melakukan tabulasi terhadap hasil jawaban dari 26 responden yaitu dengan cara menyusun hasil jawaban dan memasukkan data sesuai klasifikasi jawaban dalam bentuk tabel (lampiran 3 dan 4). Tabulasi jawaban responden dilakukan dengan bantuan program microsoft excel. Pada uji validitas peneliti melakukan perhitungan otomatis. Perhitungan otomatis dengan menggunakan rumus pearson product moment dengan bantuan SPSS (Statistical Product and Service Solutions) versi 22.00.

Hasil pengujian validitas (lampiran 5 dan 6) menunjukkan signifikan artinya bahwa semua butir pertanyaan untuk semua variabel adalah valid yang ditunjukkan dengan distribusi tabel $(0,396)$ untuk $\alpha=0,05$. Sehingga semua butir pertanyaan yang diajukan dapat digunakan untuk pengumpulan data. Hasil uji validitas variabel penelitian seperti yang tampak pada tabel berikut:

\section{Hasil Uji Reliabilitas}

Pengujian reliabilitas dalam penelitian ini menggunakan uji one shoot artinya satu kali pengukuran saja kemudian hasilnya dibandingkan dengan pernyataan lainnya untuk mengukur korelasi antara jawaban pertanyaan setiap variabel. Hasil perhitungan uji reliabilitas menunjukkan bahwa nilai croanbach alpha $(\alpha)$ 0,6 . Dengan demikian, disimpulkan bahwa item-item instrument untuk masing-masing variabel adalah reliabel.

\section{HASIL PENELITIAN DAN} PEMBAHASAN 


\section{Identitas Responden}

Untuk mengetahui karakteristik responden dapat dilihat dari klasifikasi tingkat usia, jenis kelamin, tingkat pendidikan, dan jabatan.

\section{Pembahasan}

Sesuai dengan teknis analisis data yang sudah dijelaskan pada bab sebelumnya dan setelah dilakukan pengolahan data, maka dapat peneliti uraikan sebagai berikut:

\section{Analisis Hubungan Antara Gaya} Kepemimpinan Situasional Terhadap Motivasi Kerja Karyawan pada PT Garuda Indonesia (Persero) Tbk Cabang Kupang

Analisis hubungan antara gaya kepemimpinan situasional (X) dengan motivasi kerja $(\mathrm{Y})$ maka digunakan analisis korelasi. Dengan menggunakan bantuan program SPSS versi 22.00, diperoleh hasil bahwa terdapat hubungan antara gaya kepemimpinan situasional dengan motivasi kerja karyawan pada PT Garuda Indonesia (Persero) Tbk Cabang Kupang.

Berdasarkan tabel 4.7 diperoleh besarnya nilai korelasi 0,677 (lampiran 9). Hal ini berarti bahwa jika gaya kepemimpinan situasional pada PT Garuda Indonesia (Persero) Tbk Cabang Kupang dengan menerapkan gaya kepemimpinan situasional berdasarkan pertimbangan atas faktor - faktor seperti pemimpin, pengikut, dan situasi dalam arti struktur tugas, peta kekuasaan, dan dinamika kelompok maka motivasi kerja pegawai akan meningkat, sebaliknya jika tidak menerapkan maka motivasi kerja karyawan menurun.

Malik (2010) menegaskan bahwa pemimpin dituntut untuk menciptakan dan menerapkan gaya kepemimpinan yang efekif dalam meningkatkan motivasi pada diri karyawan, sehingga pendapat tersebut membuktikan bahwa analisis hubungan dari penelitian ini diperoleh sebesar 0,677 merupakan hubungan yang tergolong positif dan kuat.

\section{Analisis Pengaruh Gaya Kepemimpinan} Situasional Terhadap Motivasi Kerja
Karyawan pada PT Garuda Indonesia (Persero) Tbk Cabang Kupang

Analisis pengaruh gaya kepemimpinan situasional (X) terhadap motivasi kerja karyawan (Y), maka digunakan analisis regresi linear sederhana. Setelah dianalisis dengan menggunakan bantuan program SPSS versi 22.00 diperoleh bahwa terdapat pengaruh positif gaya kepemimpinan situasional terhadap motivasi kerja karyawan pada PT Garuda Indonesia (Persero) Tbk Cabang Kupang ditunjukkan pada tabel 4.8 sebagai berikut:

Berdasarkan pada tabel 4.8 menunjukkan pengaruh yang positif, diperoleh nilai $\alpha=31,931$ sedangkan nilai $b$ $=0,599$ sebagai persamaan regresi dalam penelitian ini adalah $\hat{Y}=31,931+0,599 X$ (lampiran 9) sesuai dengan persamaan regresi tersebut, nampak bahwa koefisien regresi X sebesar 0,599 menyatakan bahwa setiap penambahan $1 \%$ nilai gaya kepemimpinan situasional, maka nilai motivasi bertambah 0,599. Koefisien tersebut bernilai positif sehingga dapat dikatakan bahwa arah pengaruh gaya kepemimpinan situasional terhadap motivasi kerja karyawan adalah positif.

Kreitner dan Kinicki (2000 : 248) menjelaskan para manajer perlu memahami proses psikologis ini jika mereka ingin berhasil memandu para karyawan menuju atau mencapai sasaran organisasi, dengan kata lain motivasi merupakan proses psikologis yang meningkatkan dan mengarahkan perilaku untuk mencapai tujuan. Serta, Robin dan Judge (2008 : 222) menegaskan motivasi merupakan hasil interaksi antara individu dengan situasi.

Pendapat tersebut membuktikan analisis pengaruh dengan dengan persamaan regresi linear sederhana $\hat{\mathrm{Y}}=31,931+0,599 \mathrm{X}$ yang menyatakan gaya kepemimpinan situasional berpengaruh positif terhadap motivasi kerja karyawan.

Setelah persamaan regresi telah ditentukan, selanjutnya melakukan pengujian hipotesis. Uji t dilakukan untuk menguji hipotesis secara parsial variabel bebas yakni gaya kepemimpinan situasional 
(X) terhadap variabel terikat yakni motivasi kerja karyawan (Y) pada PT Garuda Indonesia (Persero) Tbk Cabang Kupang. Hasil uji t tersebut dapat dilihat pada tabel 4.9 .

Berdasarkan tabel hasil uji $\mathrm{t}$ di atas diperoleh $\mathrm{t}$ hitung sebesar 4,417 > t tabel 2,069 maka Ho ditolak, berarti Ha diterima sehingga membuktikan hipotesis bahwa terdapat pengaruh yang signifikan antara gaya kepemimpinan situasional terhadap motivasi kerja karyawan pada PT Garuda Indonesia (Persero) Tbk Cabang Kupang.

3. Analisis Besarnya Pengaruh Gaya Kepemimpinan Situasional Terhadap Motivasi Kerja Karyawan pada PT Garuda Indonesia (Persero) Tbk Cabang Kupang

Besarnya pengaruh gaya kepemimpinan situasional terhadap motivasi kerja karyawan pada PT Garuda Indonesia (Persero) Tbk Cabang Kupang ditentukan melalui koefisien determinasi $\left(\mathrm{R}^{2}\right)$ dapat dilihat pada tabel 4.10, sebagai berikut :

Berdasarkan pada tabel 4.10 diperoleh hasil analisis data nilai $\mathrm{R}^{2}$ sebesar $45,9 \%$ (lampiran 9) . Nilai $\mathrm{R}^{2}$ sebesar $45,9 \%$ artinya gaya kepemimpinan situasional memberikan pengaruh sebesar $45,9 \%$ terhadap motivasi kerja karyawan PT Garuda Indonesia (Persero) Tbk Cabang Kupang, sedangkan sisanya sebesar $54,1 \%$ dapat dipengaruhi oleh faktor lain. Menurut Peterson dan Plowman (Hasibuan, 2017 : 142) faktor lain yang mempengaruhi motivasi adalah keinginan untuk hidup, keinginan untuk suatu posisi, keinginan akan kekuasaan dan keinginan akan pengakuan yang tidak diteliti dalam penelitian ini.

\section{PENUTUP}

\section{Kesimpulan}

Berdasarkan hasil analisis disimpulkan bahwa gaya kepemimpinan situasional yang diterapkan kepada karyawan pelaksana PT Garuda Indonesia (Persero) Tbk Cabang Kupang memberikan pengaruh signifikan terhadap motivasi kerja karyawan. Hubungan positif tersebut ditunjukkan oleh besarnya nilai koefisien korelasi (b) 0,599 yang artinya apabila gaya kepemimpinan situasional meningkat $1 \%$ maka nilai motivasi kerja karyawan akan bertambah sebesar 0,599. Besarnya pengaruh gaya kepemimpinan situasional terhadap motivasi kerja karyawan ditunjukkan melalui nilai koefisien determinasi $\left(\mathrm{R}^{2}\right)$ sebesar 45,9\%, sedangkan $54,1 \%$ dipengaruhi oleh faktor - faktor lain seperti keinginan untuk hidup, keinginan untuk suatu posisi, keinginan akan kekuasaan dan keinginan akan pengakuan yang tidak diteliti dalam penelitian ini

\section{Saran}

Berdasarkan hasil penelitian dan kesimpulan di atas, maka saran yang disampaikan peneliti adalah :

1. Karyawan sebagai bawahan kadang kurang mampu dalam melaksanakan pekerjaannya namun mereka memiliki kemauan untuk melaksanakan. Oleh karena itu, pemimpin sebagai atasan harus memberikan pengarahan dan dukungan yang kuat sehingga bawahan merasa yakin dan mampu dalam melaksanakan pekerjaan

2. Pemimpin tidak hanya sebagai pemegang keputusan, tetapi juga mau mendengarkan bawahan sehingga apabila telah diambil suatu keputusan, karyawan sebagai bawahan merasa turut andil dalam keputusan tersebut.

3. Dianjurkan kepada peneliti mendatang, agar dapat memperluas objek penelitiannya dan tidak hanya sebatas pada PT Garuda Indonesia (Persero) Tbk Cabang Kupang, tetapi dapat dilakukan di instansi lain yang terkait dengan objektivitas penilaian motivasi karyawan.

\section{DAFTAR PUSTAKA}

Adair, John. 2006. Kepemimpinan yang Memotivasi. PT Gramedia Pustaka Utama, Jakarta

Cowley, E., \& Smith, S. (2014). Motivation and mission in the public sector: Evidence from the world values survey. Theory and Decision, 76(2), 241-263. doi:http://dx.doi.org/10.1007/s11238-013 9371-6

Hamidi. 2005. Metode Penelitian Kualitatif: Aplikasi Praktis Pembuatan Proposal Dan Laporan Penelitian. Malang : UMM PRESS 
Harsey, Paul; Blanchard, Ken. 1982. Management Of Organizational Behavior: Utilizing Human Resources, 4th Edition. Prentice - Hall, Inc. Terjemahan; Diterjemahkan oleh; Dharma, Agus. Manajemen Perilaku Organisasi: Pendayagunaan Sumber Daya Manusia. Erlangga, Jakarta.

Hasibuan, Malayu S.P. 2017. Manajmen Sumber Daya Manusia Edisi Revisi. Bumi Aksara, Bandung.

Kartono, Kartini. 2005. Kepemimpinan: Apakah Kepemimpinan Abnormal itu? PT Raja Grafindo Persada, Jakarta.

Khoironi, Fifil. 2011. Pengaruh Gaya Kepemimpinan Situasional Terhadap Motivasi Kerja Karyawan Pada Taman Rekreasi Sengkaling.

Kreitner, Robert \& Kinicki, Angelo. 2000. Organizational Behavior $5^{\text {th }}$. The McGraw - Hill Companies, Inc. Terjemahan, Diterjemahkan oleh; Suandy, Erly. 2005. Prilaku Organisasi. Salemba Empat, Jakarta.

Malik, A.M. 2010. Pengaruh Gaya Kepemimpinan Situasional Tipe Konsultasi terhadap Motivasi Kerja Karyawan pada PT Astra Internasional Honda Tbk. Makassar: Fakultas Ekonomi dan Bisnis Universitas Hasanuddin.

Northouse, Peter G. 2013. Edisi Keenam. Kepemimpinan: Teori dan Praktik. PT Indeks, Jakarta

Pasolong, Harbani. 2008. Kepemimpinan Birokrasi. Alfabeta, Bandung

Riduan. 2013. Metode \& Teknik Menyusun Proposal Penelitian. Alfabeta, Bandung.

Rivai, Veithzal. 2004. Kiat Kepemimpinan Dalam Abad 21. Murai Kencana, Jakarta.

Robbins, S.P. 2006. Teori Organisasi: Struktur, Desain \& Aplikasi. Alih Bahasa : Yusuf Udaya. Arcan, Jakarta

Robins, Stephen P \& Judge, Timothy A. 2008. Perilaku Organisasi, Edisi 12, Buku 2. Diterjemahkan oleh; Angelica, Diana, dkk. Penerbit Salemba Empat, Jakarta

Sinollah. 2014. Pengaruh Gaya Kepemimpinan Situasional Terhadap Motivasi Kerja Karyawan CV Duta Bangsa Pasuruan.
Jurnal OTONOMI Volume 10. No. 2 Nopember.

Sugiyono. 2013. Metode Penelitian Administrasi. Alfabeta, Bandung.

Syaiyid, Elzi; Utami, Hamidah Nayati; Riza, Muhammad Faisal. 2013. Pengaruh Gaya Kepemimpinan Terhadap Motivasi Kerja (Studi Pada Karyawan Radar Malang PT Malang Intermedia Pers). Jurnal Administrasi Bisnis (JAB)|Vol. 1 No. 1 April. Fakultas Ilmu Administrasi, Universitas Brawijaya, Malang.

Syamsuddin, Aditya Gunawan. 2016. Pengaruh Gaya Kepemimpinan Situasional Terhadap Motivasi Kerja Karyawan Pada PT Semen Tonasa (Persero) TBK. Fakultas Ekonomi dan Bisnis, Universitas Hasanuddin, Makassar.

Thoha, Miftah. 2004. Kepemimpinan Dalam Manajemen. PT Raja Grafindo Persada, Jakarta

Thoha, Miftah. 2007. Perilaku Organisasi: Konsep Dasar dan Aplikasinya. PT Raja Grafindo Persada, Jakarta.

Tjiptono, Fendy. 2004. Prinsip-prinsip Total Quality Service. Penerbit Andi, Yogyakarta

Tzu, Sun dan Thomas Cleary. 2002. Seni Perang. Erlangga, Jakarta.

Waluyo. 2007. Manajemen Publik: Konsep. Aplikasi dan Implementasinya Dalam Pelaksanaan Otonomi Daerah. Mandar Maju, Bandung 